\title{
Spigelian hernia in the elderly
}

\author{
R M Giamattei*, L Butuc, F La Rocca, G Viola, A Mercogliano, G Fatigati, A Martino \\ From XXIII Annual Meeting of the Italian Society of Geriatric Surgery \\ Lecce, Italy. 2-4 December 2010
}

The Spigelian hernia or lateral ventral hernia is a rare clinical entity, characterized by a defect in the Seminular line. The etiology is mainly based on the anatomical features of the Spigelian aponeurosis and all those conditions that lead to increased intra-abdominal pressure (COPD, obesity, chronic constipation), typical in the elderly.

In our study, we report two cases of Spigelian hernia which appear in two patients, a 75-year-old female and a 71-year-old male, both had associated comorbidities. The female patient, suffering from hypertension and a history of diverticular disease which presents a strangulated hernia of the left abdominal wall, so, in the presence of intestinal sub-occlusion sintomatology, required emergency treatment. The second patient, suffering from hypertension, kidney stones and benign prostatic hyperplasia, reported abdominal discomfort with intense swelling, predominantly on the left of the abdominal examination. The second patient did not present complication and elective treatment was performed. The surgical technique adopted in both cases was the placement of hernioplasty with polypropylene mesh, a technique that allows a short hospital stay and early rehabilitation for the patient.

Submit your next manuscript to BioMed Central and take full advantage of:

- Convenient online submission

- Thorough peer review

- No space constraints or color figure charges

- Immediate publication on acceptance

- Inclusion in PubMed, CAS, Scopus and Google Scholar

- Research which is freely available for redistribution 